\title{
The effect of intangible service quality on retailing during the COVID-19 pandemic in Saudi Ara- bia
}

\author{
Zyad Alzaydi ${ }^{*}$
}

${ }^{a}$ College of Business administration, Albaha University, Saudi Arabia

\section{H R O N I C L E}

\section{Article history:}

Received: December 5, 2020

Received in revised format:

January 262021

Accepted: April 3, 2021

Available online:

April 5, 2021

Keywords:

Online to Offline

Online Shopping

E-commerce

Retailing

Customer Satisfaction

Revisit Intention

\section{A B S T R A C T}

The purpose of this study is to investigate how online to offline service quality influences the customer's perceived risk and trust towards the retailer and how these factors impact customer satisfaction and intention to revisit. The present study incorporates intangible service quality offline aspects, such as empathy, and online aspects, such as mobility. The objective of the research is to examine the integration of online to offline service quality models in Saudi Arabia during the COVID-19 pandemic, using key aspects of offline, online and mobile service quality. The data was collected using an online survey of 289 respondents from Saudi Arabia. The analysis was conducted using partial least square and structural equation modelling. This study finds that the intangibility of service quality has a positive impact on perceived trust; however, the direct relationship between the intangibility of service quality and perceived risk is not supported. The study's results support the hypothesis that customer satisfaction has a positive impact on the intention to revisit and that received trust positively affects satisfaction. The results have implications for service managers in the retailing and e-commerce sectors and offer a better understanding of how different channels of service affect customers' perceptions and intentions to revisit.

\section{Introduction}

By looking at the meaning of $\mathrm{O} 2 \mathrm{O}$ firms have been employing multiple channels rather than a single distribution channel to deliver products/services to customers for decades, namely through postal orders and offline retail channels (Acquila-Natale \& Iglesias-Pradas, 2020). However, with the emergence of the internet, growth in multichannel strategies, or integrating both online and offline channels, has become widespread. In distributing products and services, one of the challenges facing firms is how to combine and adjust different channels to satisfy customers' demands. The purpose of multiple channels is to expand the scope of the market share by reducing the time and product-related obstacles in the transaction process (de Oliveira, Indulska, Steen, \& Verreynne, 2020). In a classical offline market, a customer buys products and services through meeting providers in person, which helps the customer decide whether to buy the product or services or not. Nevertheless, in online markets, additional challenges can complicate this process due to the lack of proximity to the product and providers. Offline markets reduce these obstacles related to e-commerce. Consequently, offline retailers have begun to extend their businesses to customers via e-commerce to benefit from e-convenience, despite the advantages of physical proximity to customers (Chen $\&$ Chen, 2019). Moreover, with the advent of smartphones, offline markets have extended their scope to include the mobile arena, thus meeting customer expectations and their real-time demands (Kalinić, Marinković, Djordjevic, \& LiebanaCabanillas, 2019). This research examines the impact of intangible aspects of online to offline (O2O) service quality on customers' perceived risk and trust in the purchasing process, which affect customer satisfaction and revisit intention during the COVID-19 pandemic.

* Corresponding author.

E-mail address: za.alzaydi@googlemail.com (Z. Alzaydi) 


\section{Literature review}

The ubiquity of mobile devices and smartphones has dramatically changed the concept of commerce. By combining offline and online commerce, $\mathrm{O} 2 \mathrm{O}$ enhances customer satisfaction and improves the experience by facilitating commerce outside of traditional times and places (Tsai et al., 2015). O2O services require online technologies, such as smartphones, apps, mobile networks, and databases, as well as offline technologies, such as GPS, the cellular network and Wi-Fi. Micro-location systems and mobile micro-location technologies - for example, Near Field Communication (NFC), quick response (QR) codes, lowpower Bluetooth (BLE) and beacon - are also used to identify customer location. For example, a customer passing their favourite restaurant may automatically be notified of coupons via their smartphone's NFC. That customer can then order and pay for food via a mobile app, without queuing in the restaurant. As accessibility through mobile devices develops, O2O services are expected to expand into different areas, such as clothing, cosmetics and transportation. The overseas mobile payment market for O2O commerce is projected to reach 4574 billion USD by 2023 (Moon \& Armstrong, 2019). There are two different ways of enacting $\mathrm{O} 2 \mathrm{O}$ services. The first method is where offline organisations extend their online/mobile commerce channels (offline to online), and the second is where the online mobile platform provider assembles offline service retailers (online to offline) and then provides its customers with $\mathrm{O} 2 \mathrm{O}$ options (Cheng, Fu, \& de Vreede, 2018). In the first method, the offline retailers provide product/service information both on and offline and process products or implement services offline. Retailers also attempt to entice customers to their business by providing promotional information online. For instance, a customer can visit an online Albaik (fast-food chain in Saudi Arabia) store, choose a product, pay using a mobile app and collect their order offline.

\subsection{Quality of service}

Quality in service industries cannot be objectively measured like it can in the domain of manufactured goods, and therefore, it remains a relatively elusive and abstract concept (Akbaba, 2006; Khan \& Shaikh, 2011; Zeithaml, Parasuraman, \& Berry, 1990). The assessment of quality performance for services is more complex than for products because of their inherent heterogeneity, the inseparability of production and consumption, perishability and intangibility (Frochot \& Hughes, 2000). The quality of service definition in terms of the gap is between customers' expectations of service and their perceptions of the actual service provided by an organization (Parasuraman et al., 1988b). The SERVQUAL scale was developed as a survey instrument intended to measure service quality in any kind of service organization, based on five dimensions: reliability, tangibility, assurance, responsiveness and empathy (Parasuraman et al., 1988b). SERVQUAL has attracted criticism on various grounds. For example, the SERVQUAL scale is based on defining quality of service as meeting or exceeding customer expectations, but defining quality in this way is complex and, consequently, difficult to measure (Parasuraman et al., 1988b; Reeves \& Bednar, 1995). A major concern about the use of SERVQUAL questions whether expectations and perceptions should be measured separately before and after the service is experienced, respectively or whether it is acceptable to collect both sets of data at a single time point. Arguably, it is an onerous task to ask customers to fill in a questionnaire on expectations when they visit a service provider and again on perceptions when they leave. To answer this particular criticism, early studies indicated that customers who have recently experienced the service could be asked to fill in both the perceptions and expectations questionnaires at the same time (Parasuraman et al., 1994). However, expectation responses obtained this way are of little value since they are gathered after the fact and are not genuine expectations (but are tempered by experience and memory; (Tamanna, 2020). This study uses SERVQUAL as the appropriate model.

\subsection{O2O quality of service}

Several researchers argue that e-service quality needs to be evaluated differently from traditional offline settings. Many scholars have tried to develop suitable tools for this purpose. For instance, E-SQUAL was introduced by (Ananthanarayanan Parasuraman, Zeithaml, \& Malhotra, 2005). E-service quality (including E-SQUAL and WebQual) might be interpreted as 'the extent to which a website promotes an efficient and effective shopping and customisation environment' (Moon \& Armstrong, 2019, pp. 1-34). In general, e-service quality concentrates on the transaction-specific evaluation of a site, looking at the system, information and service (Barnes \& Vidgen, 2001; Kalia \& Paul, 2021). For example, for the mobile environment, service quality considers the aspects adapted for the mobile commerce context, such as personal location and customised services (Silalahi, Handayani, \& Munajat, 2017). Research has shown that high-quality service offline and in the O2O context positively impacts customer loyalty; however, service quality in an online setting did not positively impact customer loyalty (He, Cheng, Dong, \& Wang, 2016). SMS text messaging satisfaction and the reliability and efficiency of O2O service were also found to positively impact O2O satisfaction (Hwang \& Kim, 2018). Recent literature has just started to focus on $\mathrm{O} 2 \mathrm{O}$ quality of service, and more work is needed. The intangible aspects include reliability, empathy and responsiveness. Reliability means that the firm should provide the relevant service(s) to the customer in the agreed timeframe. Furthermore, the firm should keep its promises to customers. For instance, bills and records should be accurate. Empathy means that customers wish to be understood. This is especially true when the customer faces a language barrier or has some kind of disability that makes it harder to communicate. When a customer has a complaint or they are not satisfied with the service, customer services staff must attempt to understand the customer. Responsiveness means that the employees of the firm should be able to provide all the firm's services, react to customers and understand customers' needs. Employees should also be able to answer all customer questions (Parasuraman et al., 1994). Regarding the intangible aspects of quality of service in offline commerce, more research is needed to ascertain the specific characteristics of service in the online and mobile contexts. Two intangible aspects of quality of service that are frequently mentioned in the literature are the availability of the system (Ribbink, Van Riel, 
Liljander, \& Streukens, 2004; Santos, 2003; Wolfinbarger \& Gilly, 2003) and security. The availability of the system refers to whether the system is fit for its purpose. Does the website crash? Is the app secure enough to protect customer data? Any issues that occur for a customer in an online/mobile context could negatively influence the customer's perception of the brand as a whole. Thus, the availability of the system is a significant intangible aspect of quality of service. Security is another important aspect. Online/mobile customers must evaluate the risk to their financial and personal details from hackers during the transaction. Several recent studies acknowledge that security is a significant quality of service aspect (Ribbink et al., 2004; Santos, 2003; Wolfinbarger \& Gilly, 2003). This study combines the intangible quality of service aspects of offline and mobile/online past research and clarifies the notion of intangible aspects as reliability, empathy, responsiveness, system availability and security. Although they use the same technical jargon, there are distinctions between offline and $\mathrm{O} 2 \mathrm{O}$ in determining service quality. Take the example of rideshare companies Uber or Careem, wherein, via an O2O platform, the passenger's location is shared via mobile phone and then the precise cost of the taxi is confirmed. The app advises the passenger of their vehicle's whereabouts on a map and the expected time of arrival. By providing the driver's information (such as picture; phone number; and make, colour and registration plate of the vehicle), these apps offer reliable taxi services. Compared to traditional taxi services, Uber and Careem are more likely to provide a higher level of assurance because the service and each driver are evaluated by passengers. Responsiveness is quicker than with traditional taxi services because the passenger is told exactly when their services will be delivered. If the driver is not punctual or an issue occurs, the passenger can contact the taxi to sort the issue out. Food delivery apps, such as Marsool and Hunger Station, have an agreement with restaurants and operate a dashboard in an app where users can provide feedback. This provides restaurants with the opportunity to review customer feedback so they can take immediate action. Intangible quality of service factors, such as security, mobility and customisation, as well as system availability for accessibility and download speed, are significant in O2O commerce. Based on previous discussions about intangible aspects of quality of service, customisation and mobility are important. $\mathrm{O} 2 \mathrm{O}$ services facilitate exact-time customisation, where the operator provides the 'right content in the right format to the right person at the right time' (Moon \& Armstrong, 2019, pp. 1-34). There are a couple of online customisation processes (Thirumalai \& Sinha, 2009). First, information must be available to customers to help them make decisions. Second, transaction customisation facilitates individual purchases. In online purchasing, developed technologies assist retailers in recognising customer needs and delivering products that satisfy the customer (Maes et al., 1999). However, meeting all customer requirements is not an easy task, and sometimes it takes longer to deliver a customised product. The COVID-19 pandemic put customers, operators and retailers in a critical position, when many people began using apps and platforms to order products/services to meet their needs, making delivery harder.

\subsection{Perceived risk and perceived trust}

Recent research has confirmed the relationship between consequences and service quality, such as perceived risk, trust and satisfaction (Arruda Filho, Simões, \& De Muylder, 2020; Ventre \& Kolbe, 2020). For instance, a customer's experience of a shop's security enhances their perceived trust and minimises their perceived risk in the transaction process (Siau \& Shen, 2003; Suh \& Han, 2003). Kim et al. (2008) defined perceived risk as a consumer's awareness of possible negative outcomes from service. Recent research suggests that perceived includes information, financial and product risks (Crespo, Del Bosque, \& de los Salmones Sánchez, 2009). A consumer's perceived risk is a significant gateway to customer loyalty, as well as retention. Purchasing contains risk because a shop's decision might have consequences that the consumer cannot anticipate: the results of some decisions may make the customer unhappy (Hsu, Chang, \& Chuang, 2015). Financial risk can be interpreted as a possible financial loss caused by hidden costs or uncertainty around the guarantee in terms of faults or maintenance (Jacoby \& Kaplan, 1972). Financial risk refers to possible monetary loss as a result of unseen costs, the absence of warranties for errors in products or the cost of continued care. Product risk happens when the customer has low expectations of a product or the delivery of its service takes longer than it should. Information risk is tied to transaction security and confidentiality, which refers to the lack of control over one's data (Hsu et al., 2015). The e-commerce environment is based on trust that others will not behave selfishly to personally benefit (Bhalla, 2020). 'The main predictors of trust are a trustor's perception of trustee's characteristics, a definition that potentially implies a close correlation between the trustee's (retailer) service quality and the trustor's (customer) perception' (Moon \& Armstrong, 2019, pp. 1-34). In online shopping, in the absence of physical contact, trust between a trustee and a trustor is a significant aspect of successful online purchasing (Bhatti \& Rehman, 2020). Trust consists of credibility, integrity and benevolence. A customer expects credibility and integrity during a transaction and considers the retailer honest once they can complete the purchase. Benevolence is the customer's perception that the retailer wants to provide high-quality services/goods as well as make a profit. In conclusion, trust refers to the customer's confidence that they will be protected by the $\mathrm{O} 2 \mathrm{O}$ retailer and willing to depend on them. This study examines whether $\mathrm{O} 2 \mathrm{O}$ quality of service can create customer trust and if it had a positive influence on customer satisfaction and retention during the COVID-19 pandemic.

\subsection{The aim of the study and hypotheses}

This study aims to contribute to the academic and practical implications of $\mathrm{O} 2 \mathrm{O}$ commerce by achieving several research aspects. First, the research identifies the quality-of-service aspects in an $\mathrm{O} 2 \mathrm{O}$ commerce situation. Second, this research investigates the $\mathrm{O} 2 \mathrm{O}$ quality of service aspects and evaluates the effect of $\mathrm{O} 2 \mathrm{O}$ service quality on customer perceptions and 
behaviours during the COVID-19 pandemic. This research is significant in terms of recognising O2O commerce as an important alternative and simple technology solution that integrates the three service processes to offline, online and mobile. Based on the previous discussion, the following hypotheses were formulated:

$\mathbf{H}_{1}$ : Perceived $\mathrm{O} 2 \mathrm{O}$ quality of service negatively affects a customer's perceived risk.

$\mathbf{H}_{2}$ : Perceived $\mathrm{O} 2 \mathrm{O}$ quality of service will positively impact customers' perceived trust.

$\mathbf{H}_{3}$ : Perceived risk will negatively affect customer satisfaction with an $\mathrm{O} 2 \mathrm{O}$ service.

H4: Perceived trust will positively impact customer satisfaction with an $\mathrm{O} 2 \mathrm{O}$ retailer/service provider.

Hs: A high level of customer satisfaction with an $\mathrm{O} 2 \mathrm{O}$ service will positively impact revisit intention.

\subsection{Research conceptual framework and hypotheses}

In the conceptual framework hypothesised, the $\mathrm{O} 2 \mathrm{O}$ quality of service aspects influences customers' perceptions. This research suggests that the intangible aspects of $\mathrm{O} 2 \mathrm{O}$ quality of service are a significant determinant of consumer perception. In particular, for $\mathrm{O} 2 \mathrm{O}$ commerce, the higher the level of perceived service quality, the lower the level of perceived risk. For example, someone places a grocery order online. When they reach the store to collect their order, they realise some of their ordered items are out of stock. The retailer should provide alternative items of higher quality, without the customer needing to place another order. That level of service quality is needed to gain the customer's trust, which minimises their perceived risk. Ultimately, trust and perceived risk affect customer satisfaction and customer retention.

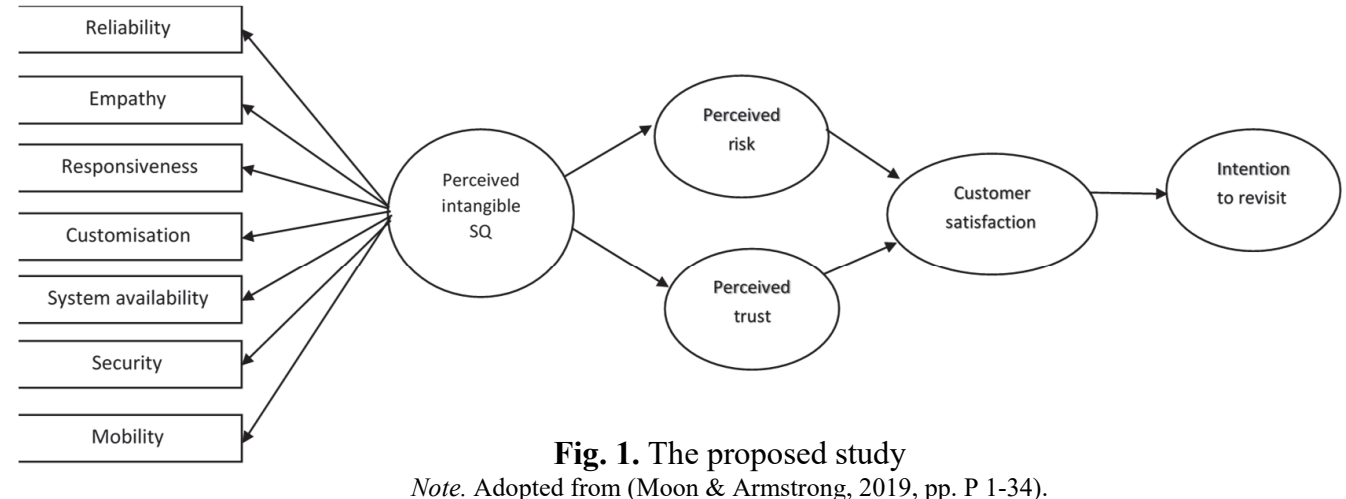

\subsection{O2O service quality and perceived risk}

In $\mathrm{O} 2 \mathrm{O}$ transactions, customers can accurately control their cost and time spent shopping by visiting online and offline channels together, rather than independently. Consumers will be aware of the risk of an $\mathrm{O} 2 \mathrm{O}$ transaction, and this might affect decisions about whether to participate in an $\mathrm{O} 2 \mathrm{O}$ transaction. Perceived risk in the shopping process is the ambiguity that customers face and the likelihood of unpredictable results (Wagner, Schramm-Klein, \& Steinmann, 2020). In general, perceived risk contains three sources: information, product and cash. Retailers can minimise customers' perceived risk of these aspects by increasing customer control when shopping (Rust \& Kannan, 2003). The tangible offline and online environments can use data to minimise perceived risk, for example, allowing people to browse products/services offline before purchasing online. In terms of intangible quality of service, when there is a breach of customer data because of a retailer's opportunistic behaviour, customers will perceive probable risks related to confidential information emerging (Degirmenci, 2020). Through the shop's intangible service quality control, information can be secured to lower this risk (Degirmenci, 2020). Customers unfamiliar with IT are more likely to perceive risk in purchasing through self-service technology (A. Parasuraman et al., 1994). Retailers may minimise this perceived risk by publicising a privacy policy.

\subsection{O2O service quality and perceived trust}

Perceived trust plays an important role in terms of the crucial aspects between the service retailer and buyer. That is the meaning of providing positive service from an $\mathrm{O} 2 \mathrm{O}$ to create customer trust. Trust is created and positively affected when the retailer provides a high level of service quality (Anderson \& Narus, 1990). Several studies support the theory about the relationship between service quality and trust (Lee, Kim, \& Ahn, 2011; Sharma \& Sharma, 2019). Chiou and Droge (2006) showed that the correlation between service quality and trust depends on agency theory. As the relationship is two-sided, agency theory utilises economic principles and understands the correlation between contract buyer (principles) and shop (agents; (Bergen, Dutta, \& Walker Jr, 1992). Agency theory clarifies that data lack of equality and opportunism are two main causes of issues in service exchange. Lack of data equality means that one party in the exchange has more data, and the other party makes decisions under ambiguity with insufficient data (Singh \& Sirdeshmukh, 2000). Chiou and Droge (2006) state that by producing explicit/tangible and implicit/intangible signals, the customer's perceived risks during a transaction can be 
minimised. Without the necessary data to shape confident expectations, customers are likely to rely on agent (retailer)-offered signals, such as employee behaviour, to assess the quality of service (Singh \& Sirdeshmukh, 2000). A suitable perception will minimise such a concern, and consumers will have more confidence in a shop, which increases a customer's trust in the retailer (Chiou \& Droge, 2006). The way of presenting the brand in-store of tangible perceived quality has a direct positive influence on brand value and trust-credibility (Konuk, 2018). A significant antecedent for enhancing buyer's trust from the store's perspective depends on (offline existence and buyer experience with a retailer) and the system depends on (simple usage, graphic) characteristics. So, the online and offline service-range alliance with mobile apps and stores may positively affect perceived trust (Harris \& Goode, 2010). In the $\mathrm{O} 2 \mathrm{O}$ trade, the influence of tangible service quality on perceived trust could be higher. Chen et al. (2015) established that among online buyers, perceived risk has a significant negative influence on satisfaction. Customers perceive risk when they detect uncertainty and ambiguity, and assume an unpleasant shopping consequence (Taylor, 1974), such as monetary or personal data loss or product shortage. Due to ambiguity, consumers attempt to avoid such conditions by not purchasing (Sharma \& Klein, 2020). Perceived risk is an important antecedent of customer satisfaction, particularly in the online shopping context, where customers usually purchase before experiencing the product/service. Perceived risk online has an important negative influence on online shopping behaviour (Saha, Zhuang, \& Li, 2020), intention to buy online and internet buying behaviour (Lu, Fan, \& Zhou, 2016). In an offline shopping context, customers might also perceive financial risk because they are not able to compare product prices with other shops. Nevertheless, less perceived risk may be expected in an $\mathrm{O} 2 \mathrm{O}$ situation. However, customers' basic trust in the $\mathrm{O} 2 \mathrm{O}$ quality of service may affect their level of satisfaction. In the online environment, previous studies have established that the absence of quality of service is directly related to a lack of trust and low customer satisfaction (Wakefield, Stocks, \& Wilder, 2004). Perceived service quality is the difference between the customer's expectations and performance (Lewis \& Booms, 1983). When performance exceeds expectations, perceived service quality is high. A high level of service quality is necessary for retailers to maintain a good relationship with the customer. In a business environment, retailers should gain customer trust that leads to customer satisfaction depending on satiability and a co-operative relationship (Pandey, Tripathi, Jain, \& Roy, 2020). In conclusion, if one group trusts another, this will lead to a positive attitude towards the second group. So, a satisfied customer will anticipate another positive shopping experience in the future. Several studies in the service sector have established that there is a strong relationship between customer satisfaction and customer loyalty (Shankar, Smith, \& Rangaswamy, 2003). Customer loyalty can be measured by the customer's behaviour and intentions and whether they repeatedly use the service/product (Uncles, Dowling, \& Hammond, 2003). Customer satisfaction means retailers need not try so hard to entice new customers but rather concentrate on keeping their existing ones, which is less expensive (Lee \& Cunningham, 2001). Customers evaluate the value of a product/service and make purchase decisions depending on their expectations. Customer retention is determined by the purchase process. According to findings from previous studies on the correlation between customer satisfaction and customer retention.

\section{Research methodology}

To examine the hypotheses, this study used scales that have been previously validated in the literature related to the suggested quality of service model. Following suggestions from previous research, the language was slightly changed to align with this study's sample. O2O quality of service includes one-dimension intangible service quality, which was examined using a fivepoint Likert-type scale ranging from 'strongly disagree' to 'strongly agree'. The nature of this study has examined the actual performance of service quality. Cronin and Taylor (1992) investigated the advantage of measuring quality of service simply in terms of customer perception of service provider performance. The authors accepted the five-dimensional structure of quality of service and 22 individual performance scale items that comprise the SERVQUAL scale (A. Parasuraman, V. Zeithaml, \& L. Berry, 1988a). That is, Cronin and Taylor originally used the same 22 performance items defined by Parasuraman and his colleagues (1988) in their study of suitable tools to measure quality of service. They compared four alternative quality of service models, including the SERVQUAL model, in four industries: banking, pest control, dry cleaning and fast food. The findings demonstrated that the performance-based scale (SERVPERF) accomplished the best fit for all four industries compared to the (P-E) SERVQUAL. Hence, SERVPERF explains more of the variance in quality of service than SERVQUAL. Furthermore, Cronin and Taylor (1992) concluded that it is more efficient to only use the performance-based scale (SERVPERF) in terms of the number of items, plus validity and reliability issues. Thus, to find the relationship between service quality and satisfaction, SERVPERF is more suitable than SERVQUAL (Cronin Jr \& Taylor, 1992). Based on the previous discussion, this study assesses quality of service using SERVPERF. In particular, perceived intangible service quality includes both offline and online aspects. Offline intangible quality of service refers to reliability (four items), empathy (three items) and responsiveness (three items). The survey did not use the original terminology; some changes were made to the questionnaire's wording to fit this research. Mobile/online intangible quality of service consists of customisation (five items), system availability (four items), security (three items), mobility (three items), perceived risk (three items), perceived trust (four items), and finally, customer satisfaction and intention (three items each). The items measured in this study were taken from previous studies. The research hypotheses were tested with data collected by questionnaire in Saudi Arabia. Participants were initially approached by email and then followed up with telephone calls inviting them to participate in the study. Saudi customers who used $\mathrm{O} 2 \mathrm{O}$ commerce during the pandemic were targeted because they used the relevant services and experienced the dimensions investigated in this study. Non-probability samples were used. Given the large number (68) and geographical spread of the respondents, a non-probability sample was applied for accessibility. Moreover, a large sample was drawn to reduce sampling error. The sample is, therefore, considered reasonably representative of the target population. 
In this research, questionnaires were used, which allowed the research questions to be answered and the hypotheses to be examined. As the targeted samples were Saudi customers, it was also expected that questionnaires would be the most effective and efficient way to elicit their perceptions regarding $\mathrm{O} 2 \mathrm{O}$ commerce. There is an additional reason for using questionnaires as the main method of data collection. Some experienced researchers in Saudi Arabia have stated that culturally, people do not demonstrate their emotions and perceptions verbally, and they prefer to answer questionnaires anonymously (Bin Saeed, 1997). Since the targeted sample included Arabic speakers, and the source language was English, back translation was used, as recommended by (Bryman, 2004). The original (English) version was translated into Arabic. Then, the Arabic was translated back into English, independent of the first English version. Any changes in meaning were corrected. Next, the second English version was translated into Arabic to produce a second Arabic version. This process was repeated until any differences in meaning were corrected. The back translations were performed by a panel of experts in English and Arabic to validate the questionnaires. The second procedure was the validation of the questionnaires by two Western-educated Saudi academics, who helped validate the Arabic versions. Third, the questionnaire was distributed to some colleagues in a PhD programme at a Saudi university to obtain their advice and suggestions. This was a basic check for obvious mistakes and oversights. This process gave the researcher an idea of the questionnaire's face-value validity (whether the questionnaire makes sense). From 400 questionnaires distributed, 289 were completed. Descriptive analysis of the respondents' answers showed that the majority of respondents ( 245 or $84.8 \%$ of the total sample) were male, and 44 or $15.2 \%$ of the total sample were female (See Fig. 2 ). The frequency and percentage of the age groups in the sample are as follows: the first age group (16-18-year-olds) accounted for $23.5 \%$ of the total sample (68 respondents). The second age group (19-27-year-olds) was the largest, accounting for 132 respondents, or $45.7 \%$ of the total sample. The third age group (28-36-year-olds) accounted for $7.3 \%$ of the total sample (21 respondents). Fifty-two respondents, $18.0 \%$ of the total sample, were in the fourth group (37-48-year-olds). The smallest number of respondents (7), or $2.4 \%$ of the total, were aged $49-55$ years old. Finally, nine respondents, or $3.1 \%$ of the total sample, were aged over 55 years. $64.7 \%$ of participants used $\mathrm{O} 2 \mathrm{O}$ commerce once or twice a week, and $17.6 \%$ shopped online three or four times a week. Regarding average weekly spend on O2O commerce, $21.1 \%$ of respondents spent 50-100 riyal, $25.3 \%$ spent $100-150$ riyal, $32.2 \%$ spent $150-300$ riyal, $10.4 \%$ spent $400-600$ riyal, and $6.9 \%$ spent $600-1000$ riyal. Moreover, the majority of online shopping was for clothing $(48.6 \%)$, furniture $(5.2 \%)$, electronic devices $(33.4 \%)$, food delivery (28.3\%) and supermarket groceries (19.3\%). People born between 1981 and 1996 continue to be the major demographic for online trade, spending more money online than any other group (Moon \& Armstrong, 2019).

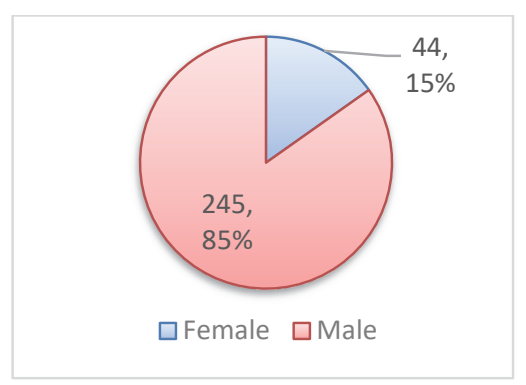

Gender

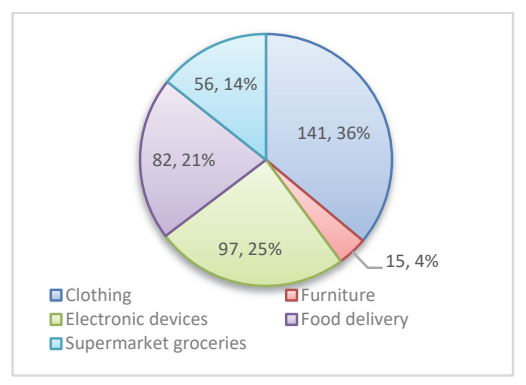

Shopping area

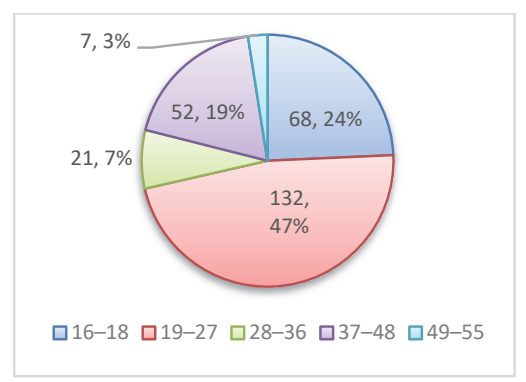

Age

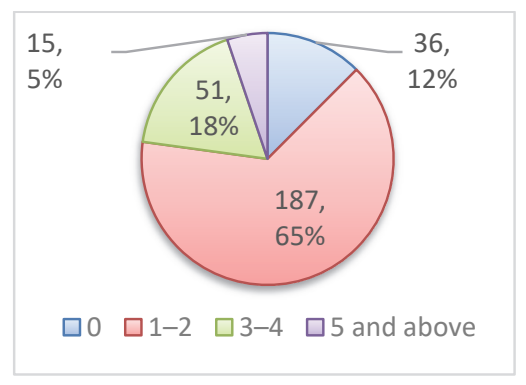

Frequency of shopping

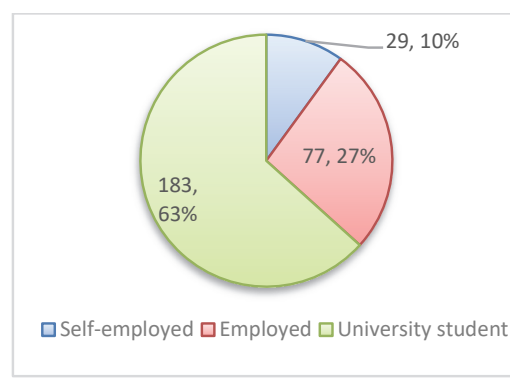

Employment

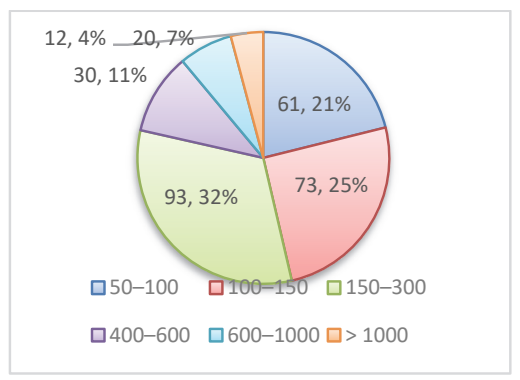

Spend per event (riyal)

Fig. 2. Personal characteristics of the participants

\section{Results}

The reliability of the survey instrument was tested with the well-known and widely accepted Cronbach's alpha. The coefficients for each construct are shown in Table 1 in the Appendix. All scales have reliability coefficients in the range of $0.8-0.9$, exceeding the cut-off level of 0.6 (Nunnally, 1978), indicating that all the instrument's alpha values are reliable. The validity of the questionnaire used can be assessed by measuring the correlation between the variables (Pallant, 2020). Criterion validity is quantified by the correlation coefficients between the sets of scales, which proves the external validity. In this study, existing theories and scales have been used. Criterion validity is checked by using the correlation matrix among factors, and if the correlation between the subscales' constructs is significant, the validity is considered approved, as shown in Table 2 in the 
Appendix. In this study, positive correlations were found between most of the variables (Hair, 2009). SEM was used to test the effect of the independent variable (H1) on the perceived intangible SQ, as shown in Table 3. The results showed that the hypotheses are unsupported. The total variance for perceived trust was $31 \%(\beta=0.557, t=5.439, \mathrm{p}<0.01)$. This result showed that the path was confirmed as positive; thus, H2 is supported, but H3 is unsupported. The result of perceived trust and customer satisfaction indicates that the standardised regression weight was significant $(\beta=0.34, t=8.156, p<0.01)$. This result demonstrated that the path was confirmed as positive, and thus, H4 is supported. The result between customer satisfaction and intention to revisit indicates that the standardised regression weight was significant $(\beta=0.52, t=11.733, p<0.01)$. This result demonstrated that the path was confirmed as positive, and thus, H5 is supported.

Table 2

The summary of some basic statistics

\begin{tabular}{|c|c|c|c|c|c|c|c|c|}
\hline Factor & Mean & SD & $\sqrt{\mathrm{AVE}}$ & AVE & Composite reliability & R square & Cronbach's alpha & Communality \\
\hline Customer satisfaction & 4.07 & 0.75 & 0.923 & 0.852 & 0.945 & 0.348 & 0.913 & 0.852 \\
\hline Customization & 3.89 & 0.73 & 0.716 & 0.512 & 0.839 & 0.724 & 0.760 & 0.512 \\
\hline Empathy & 3.87 & 0.77 & 0.822 & 0.676 & 0.862 & 0.295 & 0.760 & 0.676 \\
\hline Intention to revisit & 3.96 & 0.75 & 0.787 & 0.787 & 0.917 & 0.528 & 0.864 & 0.787 \\
\hline Mobility & 3.87 & 0.91 & 0.846 & 0.717 & 0.884 & 0.598 & 0.802 & 0.717 \\
\hline Perceived intangible SQ & 3.70 & 0.76 & 0.813 & 0.661 & 0.922 & 0.000 & 0.910 & 0.661 \\
\hline Perceived risk & 3.79 & 0.60 & 0.846 & 0.716 & 0.883 & 0.025 & 0.801 & 0.716 \\
\hline Perceived trust & 3.91 & 0.55 & 0.842 & 0.679 & 0.894 & 0.310 & 0.843 & 0.679 \\
\hline Reliability & 3.91 & 0.83 & 0.794 & 0.631 & 0.872 & 0.510 & 0.804 & 0.631 \\
\hline Responsiveness & 3.91 & 0.76 & 0.789 & 0.624 & 0.833 & 0.505 & 0.701 & 0.624 \\
\hline Security & 4.12 & 0.78 & 0.879 & 0.774 & 0.911 & 0.655 & 0.854 & 0.774 \\
\hline System availability & 3.72 & 0.76 & 0.767 & 0.589 & 0.849 & 0.630 & 0.761 & 0.589 \\
\hline
\end{tabular}

Table 3

The results of correlation matrix

\begin{tabular}{|c|c|c|c|c|c|c|c|c|c|c|c|}
\hline 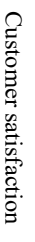 & 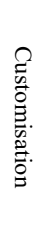 & 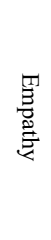 & 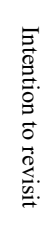 & $\begin{array}{l}3 \\
\frac{3}{0} \\
\text { E. }\end{array}$ & 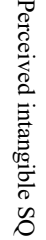 & 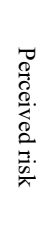 & 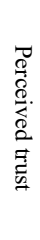 & 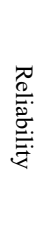 & 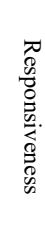 & 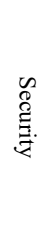 & 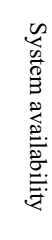 \\
\hline
\end{tabular}

\begin{tabular}{|c|c|c|c|c|c|c|c|c|c|c|c|c|}
\hline Customer satisfaction & 1.000 & & & & & & & & & & & \\
\hline Customisation & $0.595^{* *}$ & 1.000 & & & & & & & & & & \\
\hline Empathy & $0.333^{* *}$ & $0.408^{* *}$ & 1.000 & & & & & & & & & \\
\hline Intention to revisit & $0.727 * *$ & $0.563^{* *}$ & $0.342 * *$ & 1.000 & & & & & & & & \\
\hline Mobility & $0.673 * *$ & $0.581 * *$ & $0.255^{* *}$ & $0.593 * *$ & 1.000 & & & & & & & \\
\hline Perceived intangible SQ & $0.732 * *$ & $0.851^{* *}$ & $0.543 * *$ & $0.684 * *$ & $0.774 * *$ & 1.000 & & & & & & \\
\hline Perceived risk & -0.032 & 0.145 & 0.150 & 0.096 & 0.099 & 0.157 & 1.000 & & & & & \\
\hline Perceived trust & $0.589 * *$ & $0.484 * *$ & $0.247 * *$ & $0.580 * *$ & $0.438 * *$ & $0.557 * *$ & 0.004 & 1.000 & & & & \\
\hline Reliability & $0.541 * *$ & $0.624 * *$ & $0.336^{* *}$ & $0.518 * *$ & $0.526 * *$ & $0.714 * *$ & 0.051 & $0.554 * *$ & 1.000 & & & \\
\hline Responsiveness & $0.546^{* *}$ & $0.538^{* *}$ & $0.433^{* *}$ & $0.521 * *$ & $0.467 * *$ & $0.711 * *$ & 0.048 & $0.370 * *$ & $0.490 * *$ & 1.000 & & \\
\hline Security & $0.569 * *$ & $0.616^{* *}$ & $0.304 * *$ & $0.499 * *$ & $0.581 * *$ & $0.809 * *$ & 0.085 & $0.438 * *$ & $0.596^{* *}$ & $0.459 * *$ & 1.000 & \\
\hline System availability & $0.562 * *$ & $0.576^{* *}$ & $0.328 * *$ & $0.557 * *$ & $0.548^{* *}$ & $0.794 * *$ & 0.179 & $0.483 * *$ & $0.593^{* *}$ & $0.454 * *$ & $0.585^{* *}$ & 1.000 \\
\hline
\end{tabular}

Table 4

The summary of the regression analysis

\begin{tabular}{|c|c|c|c|}
\hline Path & Coefficient path $(\beta)$ & $T$ Statistics & Remark \\
\hline Perceived intangible $S Q \rightarrow$ Perceived Risk & 0.157 & 1.170 & Unsupported \\
\hline Perceived intangible SQ $\rightarrow$ Perceived Trust & 0.557 & $* * 5.439$ & Supported \\
\hline Perceived Risk $\rightarrow$ Customer satisfaction & -0.034 & 0.332 & Unsupported \\
\hline Perceived Trust $\rightarrow$ Customer satisfaction & 0.589 & $* * 8.156$ & Supported \\
\hline Customer satisfaction $\rightarrow$ Intention to revisit & 0.727 & $* * 11.733$ & Supported \\
\hline
\end{tabular}

\section{Discussion}

$\mathrm{O} 2 \mathrm{O}$ commerce and integrated technologies are progressing, but this domain would benefit from new strategies that associate $\mathrm{O} 2 \mathrm{O}$ technology with effective business models to produce more revenue. Thus, the current study investigates the $\mathrm{O} 2 \mathrm{O}$ service quality aspects that customers perceive as significant. First, this study provides empirical evidence that when developing $\mathrm{O} 2 \mathrm{O}$ services, intangible factors should be considered. Second, this study discovers how O2O quality of service composed of intangible service impacts perceived risk and revisit intention. This research presents the $\mathrm{O} 2 \mathrm{O}$ quality of service model from 
the perspective of intangible service quality. $\mathrm{O} 2 \mathrm{O}$ is a new commercial environment that merges offline, online and mobile settings. 'The $\mathrm{O} 2 \mathrm{O}$ model characterises a firm's offline interactions with customers as providing a stabilising anchor to build customers' trust and improve their satisfaction when doing business with the firm' (Moon \& Armstrong, 2019, pp. P 1-34) This research utilises a quality of service measure previously used by a study of offline, online and mobile apps that may apply to the $\mathrm{O} 2 \mathrm{O}$ commerce environment and COVID-19 pandemic period (Moon \& Armstrong, 2019). This is one of the first studies to conceptualise intangibles in Saudi Arabia during the COVID-19 pandemic of service quality factors in an O2O context. Intangible quality of service along with intangibility on $\mathrm{O} 2 \mathrm{O}$ commerce contains three offline aspects (reliability, empathy and responsiveness) and three online/mobile aspects (system availability, security and mobility). Customisation can also be applied to both online/mobile and offline commerce processes. $\mathrm{O} 2 \mathrm{O}$ may offer immediate service fit to the single customer's preference, namely, 'service suits you' in the entire shopping journey. Therefore, this research has clearly defined $\mathrm{O} 2 \mathrm{O}$ quality of service as intangible in online/mobile and offline commerce.

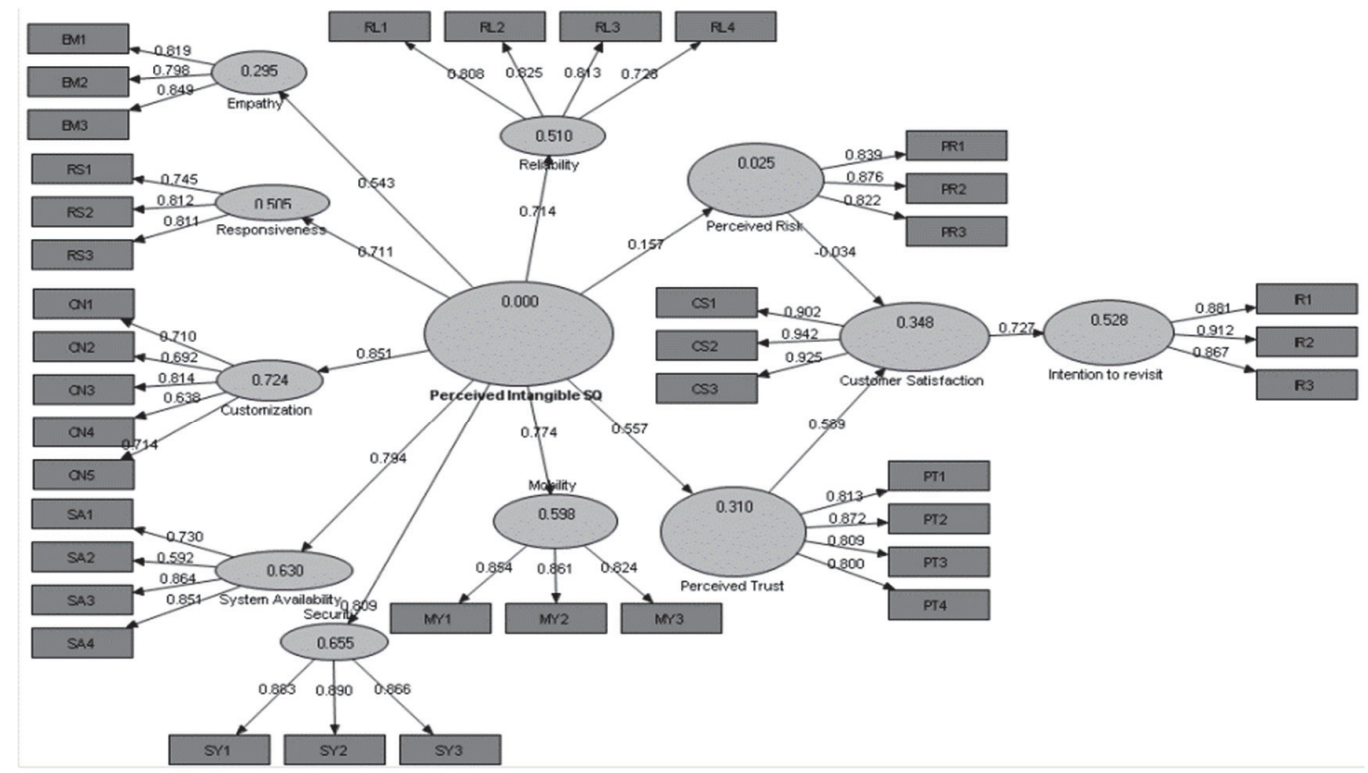

Fig. 3. Factor Loading, Path Coefficient and $\mathrm{R} 2(\mathrm{~N}=289)$

The findings show that $\mathrm{O} 2 \mathrm{O}$ is an important determinant of customer perceptions and behaviours. The findings support the idea that high-quality service should provide better-perceived trust and minimise the perceived risk of both products and services as well. Customers believe that the risks connected to product deformity, chances cost and their data, such as privacy infiltration, are low when an $\mathrm{O} 2 \mathrm{O}$ retailer provides a high level of service quality. Perceived trust also improves because a high level of service quality is indicative of a retailer's integrity. Intangible service quality, such as a provider's behaviour and empathy, as well as customer perception of retailer reliability, security and mobility that lets anyone order anywhere at any time, may increase positive perceptions, leading to more positive customer reactions, such as satisfaction and revisit intention.

\section{Limitation and direction for further research}

All research has its limitations, and this study is no exception. There are two fields in which limitations can be identified: conceptual and methodological. The logic of social science studies always draws attention to the issue of what variables should or could have been involved in the study. In this study, the number of possible variables was endless, given the long history of research into tangible perceived service quality, such as ambient conditions and facility and design aesthetics on perceived risk and perceived trust. This study examined O2O commerce during the COVID-19 pandemic. Future research might focus on a specific industry, like restaurants, because the influence of offline service quality depends on the kind of service provided: the effect of offline service quality in a café is stronger than in food delivery. Further analysis in terms of these interrelations is needed. Moreover, future research could take a demographic approach, looking at the moderating effects of personal characteristics, such as education level and age. In addition to the aforementioned conceptual limitations, several methodological limitations apply to this study. Some are cultural concerns, such as the small number of female respondents due to the conservative Saudi nature. This study's methodology was developed and validated elsewhere in the literature: a quantitative approach was appropriate and justified. Nevertheless, Bryman (2004) and Conger (1998) said that to fully understand the complexities involved in studying behaviours, a qualitative focus is equally appropriate.

\section{Conclusion}

This research has defined $\mathrm{O} 2 \mathrm{O}$ in terms of intangible service quality in the COVID-19 period and discusses the correlation between intangible service quality and customer perception and behaviours. It also mentions the practical implementations of 
using technology and websites, particularly during the COVID-19 pandemic, and how they play an important role in the O2O market. The results show that intangible service quality has a weak positive effect on perceived risk, indicating that customers are more concerned about receiving their orders than security. This point should be highlighted for firms and retailers, so that in the future, to maintain the relationships forged during the pandemic, they employ sophisticated technology to allow customers more customisation in their online purchases and orders. Additionally, the study shows that the average person shopped online between one and three times per week and spent 300-600 riyal in that period. The results indicate that e-commerce is growing in Saudi Arabia, and with it, shopping behaviour, attitude and norms are changing, putting pressure on retailers and firms to establish new strategies to survive. The empirical findings also demonstrate that customers' commercial experiences online (via website or app) contribute to increased perceived trust, leading to greater customer satisfaction and revisit intention. Thus, marketing managers could benefit from this study's findings by developing new ways of implementing $\mathrm{O} 2 \mathrm{O}$ operations.

\section{Acknowledgements}

I would like to thank Albaha University, especially the College of Business Administration, for their continuous support.

\section{References}

Acquila-Natale, E., \& Iglesias-Pradas, S. (2020). How to measure quality in multi-channel retailing and not die trying. Journal of Business Research, 109(5), 38-48. doi:https://doi.org/10.1016/j.jbusres.2019.10.041

Akbaba, A. (2006). Measuring service quality in the hotel industry: A study in a business hotel in Turkey. International Journal of Hospitality Management, 25(2), 170-192. doi:https://doi.org/10.1016/j.ijhm.2005.08.006

Anderson, J. C., \& Narus, J. A. (1990). A model of distributor firm and manufacturer firm working partnerships. Journal of Marketing, 54(1), 42-58.

Arruda Filho, E. J. M., Simões, J. D. S., \& De Muylder, C. F. (2020). The low effect of perceived risk in the relation between hedonic values and purchase intention. Journal of Marketing Management, 36(1-2), 128-148. doi:https://doi.org/10.1080/0267257x.2019.1697725

Barnes, S. J., \& Vidgen, R. (2001). An evaluation of cyber-bookshops: the WebQual method. International journal of electronic commerce, 6(1), 11-30. doi:https://doi.org/10.1080/10864415.2001.11044225

Bergen, M., Dutta, S., \& Walker Jr, O. C. (1992). Agency relationships in marketing: A review of the implications and applications of agency and related theories. Journal of marketing, 56(3), 1-24. doi:https://doi.org/10.1177/002224299205600301

Bhalla, S. (2020). Demystifying the Key Antecedents of Consumer Trust in Online Shopping and Testing the Mediating Role of Consumer Trust: An Empirical Study. IUP Journal of Marketing Management, 19(1), 7-22.

Bhatti, A., \& Rehman, S. U. (2020). Perceived benefits and perceived risks effect on online shopping behavior with the mediating role of consumer purchase intention in Pakistan. International Journal of Management Studies, 26(1), 33-54. doi:https://doi.org/10.32890/ijms.26.1.2019.10512

Bin Saeed, K. (1997). Total Quality Management: Applications in Health Sector. Riyadh: Obekan Publishing.

Bryman, A. (2004). Research methods and organization studies (Vol. 20). Oxford: Oxford University.

Chen, J., \& Chen, B. (2019). When should the offline retailer implement price matching? European Journal of Operational Research, 277(3), 996-1009.

Cheng, X., Fu, S., \& de Vreede, G.-J. (2018). A mixed method investigation of sharing economy driven car-hailing services: Online and offline perspectives. International Journal of Information Management, 41(8), 57-64. doi:https://doi.org/10.1016/j.ijinfomgt.2018.03.005

Chiou, J.-S., \& Droge, C. (2006). Service quality, trust, specific asset investment, and expertise: Direct and indirect effects in a satisfaction-loyalty framework. Journal of the academy of marketing science, 34(4), 613. doi:https://doi.org/10.1177/0092070306286934

Crespo, Á. H., Del Bosque, I. R., \& de los Salmones Sánchez, M. G. (2009). The influence of perceived risk on Internet shopping behavior: a multidimensional perspective. Journal of Risk Research, 12(2), 259-277. doi:https://doi.org/10.1080/13669870802497744

Cronin Jr, J. J., \& Taylor, S. A. (1992). Measuring service quality: a reexamination and extension. The Journal of Marketing, $16(3), 55-68$.

de Oliveira, R. T., Indulska, M., Steen, J., \& Verreynne, M.-L. (2020). Towards a framework for innovation in retailing through social media. Journal of Retailing and Consumer Services, 54.

Degirmenci, K. (2020). Mobile users' information privacy concerns and the role of app permission requests. International Journal of Information Management, 50(2), 261-272. doi:https://doi.org/10.1016/j.ijinfomgt.2019.05.010

Frochot, I., \& Hughes, H. (2000). HISTOQUAL: The development of a historic houses assessment scale. Tourism management, 21(2), 157-167. doi:https://doi.org/10.1016/s0261-5177(99)00045-X

Hair, J. F. (2009). Multivariate Data Analysis: A Global Perspective. (7th ed.). Upper Saddle River: Prentice Hall, 2009. Print.

Harris, L. C., \& Goode, M. M. (2010). Online servicescapes, trust, and purchase intentions. Journal of Services Marketing, 230-243. doi:https://doi.org/10.1108/08876041011040631 
He, Z., Cheng, T., Dong, J., \& Wang, S. (2016). Evolutionary location and pricing strategies for service merchants in competitive O2O markets. European Journal of Operational Research, 254(2), 595-609. doi:https://doi.org/10.1016/j.ejor.2016.03.030

Hsu, M.-H., Chang, C.-M., \& Chuang, L.-W. (2015). Understanding the determinants of online repeat purchase intention and moderating role of habit: The case of online group-buying in Taiwan. International Journal of Information Management, 35(1), 45-56. doi:https://doi.org/10.1016/j.ijinfomgt.2014.09.002

Hwang, S., \& Kim, S. (2018). Does mIM experience affect satisfaction with and loyalty toward O2O services? Computers in Human Behavior, 82(5), 70-80. doi:https://doi.org/10.1016/j.chb.2017.12.044

Jacoby, J., \& Kaplan, L. B. (1972). The components of perceived risk. ACR Special Volumes, 3, 382-393.

Kalia, P., \& Paul, J. (2021). E-service quality and e-retailers: Attribute-based multi-dimensional scaling. Computers in Human Behavior, 115(2), 106608. doi:https://doi.org/10.1016/j.chb.2020.106608

Kalinić, Z., Marinković, V., Djordjevic, A., \& Liebana-Cabanillas, F. (2019). What drives customer satisfaction and word of mouth in mobile commerce services? A UTAUT2-based analytical approach. Journal of Enterprise Information Management.

Khan, N. U. R., \& Shaikh, U. A. A. (2011). Impact of service quality on customer satisfaction: evidences from the restaurant industry in Pakistan. Management \& Marketing-Craiova(2), 343-355.

Konuk, F. A. (2018). The role of store image, perceived quality, trust and perceived value in predicting consumers' purchase intentions towards organic private label food. Journal of Retailing and Consumer Services, 43(7), 304-310. doi:https://doi.org/10.1016/j.jretconser.2018.04.011

Lee, J., Kim, H. J., \& Ahn, M. J. (2011). The willingness of e-Government service adoption by business users: The role of offline service quality and trust in technology. Government information quarterly, 28(2), $222-230$. doi:https://doi.org/10.1016/j.giq.2010.07.007

Lee, M., \& Cunningham, L. F. (2001). A cost/benefit approach to understanding service loyalty. Journal of Services Marketing, 15(2), 113-130. doi:https://doi.org/10.1108/08876040110387917

Lewis, R. C., \& Booms, B. H. (1983). The marketing aspects of service quality. Emerging perspectives on services marketing, 65(4), 99-107.

Lu, B., Fan, W., \& Zhou, M. (2016). Social presence, trust, and social commerce purchase intention: An empirical research. Computers in Human Behavior, 56(4), 225-237. doi:https://doi.org/10.1037/t47701-000

Maes, P., Guttman, R. H., \& Moukas, A. G. (1999). Agents that buy and sell. Communications of the ACM, 42(3), 81-ff. doi:https://doi.org/10.1145/295685.295716

Moon, Y., \& Armstrong, D. J. (2019). Service quality factors affecting customer attitudes in online-to-offline commerce. Information Systems and e-Business Management, 18(12), 1-34. doi:https://doi.org/10.1007/s10257-019-00459-y

Pallant, J. (2020). SPSS survival manual: A step by step guide to data analysis using IBM SPSS: Routledge.

Pandey, N., Tripathi, A., Jain, D., \& Roy, S. (2020). Does price tolerance depend upon the type of product in e-retailing? Role of customer satisfaction, trust, loyalty, and perceived value. Journal of Strategic Marketing, 28(6), 522-541. doi:https://doi.org/10.1080/0965254x.2019.1569109

Parasuraman, A., Zeithaml, V., \& Berry, L. (1988a). SERVQUAL: a multiple-item scale for measuring consumer perceptions of service quality. Journal of Retailing, 64(1), 12-40.

Parasuraman, A., Zeithaml, V. A., \& Berry, L. (1988b). SERVQUAL: A multiple-item scale for measuring consumer perceptions of service quality. 1988, 64(1), 12-40.

Parasuraman, A., Zeithaml, V. A., \& Berry, L. L. (1994). Reassessment of expectations as a comparison standard in measuring service quality: implications for further research. The Journal of Marketing, 58(1), 111-124.

Parasuraman, A., Zeithaml, V. A., \& Berry, L. L. (1994). Reassessment of expectations as a comparison standard in measuring service quality: implications for further research. Journal of marketing, 58(1), 111-124. doi:https://doi.org/10.1177/002224299405800109

Parasuraman, A., Zeithaml, V. A., \& Malhotra, A. (2005). ES-QUAL: A multiple-item scale for assessing electronic service quality. Journal of service research, 7(3), 213-233. doi:https://doi.org/10.1177/1094670504271156

Reeves, C. A., \& Bednar, D. A. (1995). Quality as symphony. The Cornell Hotel and Restaurant Administration Quarterly, 36(3), 72-79.

Ribbink, D., Van Riel, A. C., Liljander, V., \& Streukens, S. (2004). Comfort your online customer: quality, trust and loyalty on the internet. Managing Service Quality: An International Journal, 14(6), 446-456. doi:https://doi.org/10.1108/09604520410569784

Rust, R. T., \& Kannan, P. (2003). E-service: a new paradigm for business in the electronic environment. Communications of the ACM, 46(6), 36-42. doi:https://doi.org/10.1145/777313.777336

Saha, S. K., Zhuang, G., \& Li, S. (2020). Will Consumers Pay More for Efficient Delivery? An Empirical Study of What Affects E-Customers' Satisfaction and Willingness to Pay on Online Shopping in Bangladesh. Sustainability, 12 (3), 1121. doi:https://doi.org/10.3390/su12031121

Santos, J. (2003). E-service quality: a model of virtual service quality dimensions. Managing Service Quality: An International Journal, 13(3), 233-246. doi:https://doi.org/10.1108/09604520310476490

Shankar, V., Smith, A. K., \& Rangaswamy, A. (2003). Customer satisfaction and loyalty in online and offline environments. International journal of research in marketing, 20(2), 153-175. doi:https://doi.org/10.1016/s0167-8116(03)00016-8 
Sharma, S. K., \& Sharma, M. (2019). Examining the role of trust and quality dimensions in the actual usage of mobile banking services: An empirical investigation. International Journal of Information Management, 44, 65-75.

Sharma, V. M., \& Klein, A. (2020). Consumer perceived value, involvement, trust, susceptibility to interpersonal influence, and intention to participate in online group buying. Journal of Retailing and Consumer Services, 52(1), 101946. doi:https://doi.org/10.1016/j.jretconser.2019.101946

Siau, K., \& Shen, Z. (2003). Building customer trust in mobile commerce. Communications of the ACM, 46(4), 91-94. doi:https://doi.org/10.1145/641205.641211

Silalahi, S. L. B., Handayani, P. W., \& Munajat, Q. (2017). Service quality analysis for online transportation services: Case study of GO-JEK. Procedia Computer Science, 124(12), 487-495. doi:https://doi.org/10.1016/j.procs.2017.12.181

Singh, J., \& Sirdeshmukh, D. (2000). Agency and trust mechanisms in consumer satisfaction and loyalty judgments. Journal of the academy of marketing science, 28(1), 150-167. doi:https://doi.org/10.1177/0092070300281014

Suh, B., \& Han, I. (2003). The impact of customer trust and perception of security control on the acceptance of electronic commerce. International journal of electronic commerce, $7(3), \quad 135-161$. doi:https://doi.org/10.1080/10864415.2003.11044270

Tamanna, T. (2020). Consumer Perceptions and Expectations of Service Quality: Assessment through SERVQUAL Dimensions. Journal of Economics and Business, 3(2), 7. doi:https://doi.org/10.31014/aior.1992.03.02.213

Taylor, J. W. (1974). The role of risk in consumer behavior: A comprehensive and operational theory of risk taking in consumer behavior. Journal of marketing, 38(2), 54-60. doi:https://doi.org/10.1177/002224297403800211

Thirumalai, S., \& Sinha, K. K. (2009). Customization strategies in electronic retailing: Implications of customer purchase behavior. Decision Sciences, 40(1), 5-36. doi:https://doi.org/10.1111/j.1540-5915.2008.00222.x

Tsai, T.-M., Wang, W.-N., Lin, Y.-T., \& Choub, S.-C. (2015). An O2O commerce service framework and its effectiveness analysis with application to proximity commerce. Procedia Manufacturing, 3(10), 3498-3505. doi:https://doi.org/10.1016/i.promfg.2015.07.668

Uncles, M. D., Dowling, G. R., \& Hammond, K. (2003). Customer loyalty and customer loyalty programs. Journal of consumer marketing, 20(4), 294-316. doi:https://doi.org/10.1108/07363760310483676

Ventre, I., \& Kolbe, D. (2020). The Impact of Perceived Usefulness of Online Reviews, Trust and Perceived Risk on Online Purchase Intention in Emerging Markets: A Mexican Perspective. Journal of International Consumer Marketing, 32(4), 287-299. doi:https://doi.org/10.1080/08961530.2020.1712293

Wagner, G., Schramm-Klein, H., \& Steinmann, S. (2020). Online retailing across e-channels and e-channel touchpoints: Empirical studies of consumer behavior in the multichannel e-commerce environment. Journal of Business Research, 107(2), 256-270. doi:https://doi.org/10.1016/i.jbusres.2018.10.048

Wakefield, R. L., Stocks, M. H., \& Wilder, W. M. (2004). The role of web site characteristics in initial trust formation. Journal of Computer Information Systems, 45(1), 94-103.

Wolfinbarger, M., \& Gilly, M. C. (2003). eTailQ: dimensionalizing, measuring and predicting etail quality. Journal of retailing, 79(3), 183-198. doi:https://doi.org/10.1016/s0022-4359(03)00034-4

Zeithaml, V. A., Parasuraman, A., \& Berry, L. L. (1990). Delivering quality service: Balancing customer perceptions and expectations: Simon and Schuster. 
(C) 2021 by the authors; licensee Growing Science, Canada. This is an open access article distributed under the terms and conditions of the Creative Commons Attribution (CC-BY) license (http://creativecommons.org/licenses/by/4.0/). 